\title{
Genetic variability of Rhizoctonia solani Kühn and its resistance to fungicides
}

\section{Castillo $\mathbf{R F}^{1}$, Gallegos $\mathrm{G}^{2}$, Flores $\mathrm{OA}^{2}$, Aguilar $\mathrm{GC}^{3}$, Rodriguez $\mathbf{H R}^{3}$ and Hernandez CFD ${ }^{2, *}$}

${ }^{1}$ Saltillo Experimental Station, Instituto Nacional de Investigaciones Forestales Agrícolas y Pecuarias. Carr. SaltilloZacatecas km 342+119, No. 9515, Col. ExHacienda de Buenavista, Saltillo, Coah. C.P. 25315

${ }^{2}$ Department of Agricultural Parasitology, Universidad Autónoma Agraria Antonio Narro, Buenavista, 25315, Saltillo, Coahuila, México

${ }^{3}$ Food Research Department, School of Chemical Sciences, Universidad Autónoma de Coahuila, 25000, Saltillo, Coahuila, Mexico

Castillo RF, Gallegos G, Flores OA, Aguilar GC, Rodriguez HR, Hernandez CFD 2020 - Genetic Variability of Rhizoctonia solani Kühn and its Resistance to Fungicides in Mexico. Studies in Fungi 5(1), 381-391, Doi 10.5943/sif/5/1/19

\begin{abstract}
The aims of this study are to determine the population genetic structure of Rhizoctonia solani, associated with potato, and to assess its resistance degree to pencycuron and thiabendazole fungicides. A total of 57 strains of $R$. Solani were isolated from different potato crop fields in Mexico, and were classified according to their anastomosis group (AG) using the polymerase chain reaction (PCR) and restriction fragment length polymorphism (RFLP)-based analysis. Then, the amplified fragments were digested with four different endonucleases (Mse I, Ava II, Mun I and Hinc II). The Repetitive Element Sequence-Based PCR (rep-PCR) technique was used to determine the genetic diversity in $R$. solani populations. Results obtained by PCR-RFLP showed that $81 \%$ of the isolates were identified as belonging to AG-3 group, 14\% to AG1-1B and 5\% to AG-11 group. In response to fungicides inhibition, $\mathrm{IC}_{50}$ between $0.014-0.039 \mathrm{mg}$ a.i./L for pencycuron, and 0.82 to 2.91 for thiabendazole were determined, This $\mathrm{IC}_{50}$ value showed that the resistance factor (RF) values ranged from 1.4 to 3.945 and 0.27 to 0.97 , respectively; this tendency suggests that isolates are susceptible to thiabendazole. The AG groups showed a heterogeneous resistance to pencycuron and thiabendazole, being more tolerant to these fungicides AG1-1B and AG-11 groups. The genetic analysis shows a low genetic diversity among (P-value 0.3225) and within (P-value 0.3275) populations; this can indicate a clonal reproduction and little parasexual cycle among the analyzed isolations.
\end{abstract}

Key words - Anastomosis group - genetic-diversity - genetic-resistance - Mexico - PCR-RFLP parasexual cycle - REP-PCR - Wright's statistics

\section{Introduction}

In Mexico, potato is one of the most important annual crops and because of the total area dedicated to this commodity and its high production costs, most of the crop cost is spent on pest control. Rhizoctonia solani [Teleomorph: Thanatephorus cucumeris (Frank) Donk] is a pathogenic fungus that attacks potato (Solanum tuberosum L.), where the main observed symptoms in damaged plants are black scurf on tubers and stem; and stolon canker on underground stems. For 
this reason, the disease is called black scurf disease of potato. This disease occurs wherever potatoes are grown, however, $R$. solani causes economically significant damage when growing climatic conditions are cool, and the soil is wet (Banville 1989). However, indistinctly from the producing area, pencycuron and thiabendazole fungicide applications are carried out to avoid infection, since the production of black-spotted tuber loses quality and commercial value. The frequent application of fungicide can induce resistance in plant pathogens (Chen et al. 2012, Mu et al. 2017).

Usually, the AG-3 group is the most commonly associated with potato production areas (Ceresini et al. 2002, Woodhall et al. 2007, Lehtonen et al. 2008a, Bolton et al. 2010), although another AG are reported such as: AG-2, AG-4, AG-5 and AG-7 (Holguin 1999, Virgen et al. 2000, Hernández et al. 2001, 2005, Woodhall et al. 2007). Rhizoctonia solani is commonly found in soil, infecting more than 200 plant species (Ogoshi 1996, Lehtonen et al. 2008a, Wibberg et al. 2013, Hane et al. 2014, Hannukkala et al. 2016, Huynh \& Akihiro 2016). Based on hyphal anastomosis between strains, 14 genetically distinct groups (AG) had been defined (Carling et al. 2002, González 2002, Guillemaut et al. 2003, Wibberg et al. 2013, Hane et al. 2014). Each AG is considered an independent entity, evolutionary or phylo-species (Cubeta \& Vilgalys 1997, Carling et al. 2002, Pannecoucque et al. 2008, Sturrock et al. 2015) because exchange, and recombination occurs only between compatible strains (Anderson 1982, Stacy \& Kenneth 2004). The specific identification of the anastomosis group is related to efficient disease management, because each anastomosis group has differential pathogenicity, and response to temperature, soil texture, etc. (Pannecoucque et al. 2008, Bolton et al. 2010, Goswami et al. 2011), and sensitivity to fungicides (Kataria et al. 1991, Lehtonen et al. 2008b, LaMondia 2012).

The knowledge of $R$. solani in regard to amount and distribution of genetic variation within and between groups is important for understanding biology of pathogen populations, and to infer the relative impact of different evolutionary forces that influence its biology, and thus predict the evolutionary potential of populations within agricultural ecosystems. The studies which generate information contribute to a better understanding of crop-pathogen patho-system, and therefore aid to design new management strategies through knowledge of their genetic structure, and monitoring of fungicides sensitivity. The objectives of this study were: 1) to determine the genetic variability of $R$. solani anastomosis groups more commonly found in different Mexican potato (Solanum tuberosum) regions, and 2) to estimate $R$. solani AG resistance to pencycuron and thiabendazole fungicides.

\section{Materials \& Methods}

\section{Sampling locations}

In randomly chosen commercial lots from five Mexican states (Nuevo Leon, Coahuila, Sonora, Jalisco and Chihuahua) potato tubers, and tissues were collected. Each sample was identified, and transferred under controlled temperature conditions $\left(5 \pm 1^{\circ} \mathrm{C}\right)$ to the Agricultural Parasitology Department the Universidad Autonoma Agraria Antonio Narro in Saltillo, Mexico.

\section{Isolation of Rhizoctonia solani strains}

Strains of Rhizoctonia solani were isolated from plant tissue with disease symptoms, and sclerotic tissue present in tubers. Fragments adjacent to wound and/or sclerotic tissue were cut, and disinfected with sodium hypochlorite at $3 \%(\mathrm{v} / \mathrm{v})$, for two minutes, then, rinsed three times with sterile distilled water. After, fragments were allowed to dry and seeded on potato dextrose-agar (PDA). The fragments were incubated at $24 \pm 0.2^{\circ} \mathrm{C}$, until fungal tissue was observed. The colonies were purified though the hyphal tip from colonies, with macroscopic characteristics typical of $R$. solani, such as development, and change of mycelial color, and appearance; branching of hyphae, and existence of multinucleate cells were also determined (Parmeter \& Whitney 1970). 


\section{Anastomosis group characterization}

The AG identification of each strain was performed using the PCR-RFLP technique (Guillemaut et al. 2003). Total genomic DNA was isolated from fresh mycelium (100 mg) by Dellaporta et al. (1983) technique, after which DNA integrity was analyzed by electrophoresis in agarose gels (1\%); staining with ethidium bromide and visualizing with UV light. This DNA was amplified by PCR using $25 \mu \mathrm{L}$ final volume amplification reaction: DNA100 ng (2 $\mu \mathrm{L})$, buffer 10x $(2.5 \mu \mathrm{L}), \mathrm{MgCl}_{2} 50 \mathrm{mM}(1 \mu \mathrm{L})$, dntp's $2 \mathrm{mM}(2 \mu \mathrm{L})$, primer $10 \mathrm{pM}(1.5 \mu \mathrm{L})$, and Taq DNA polymerase at $5 \mathrm{U} / \mu \mathrm{L}(0.25 \mu \mathrm{L})$. The PCR program: $94^{\circ} \mathrm{C}$ for $5 \mathrm{~min}, 35$ cycles at $94^{\circ} \mathrm{C}$ for $1 \mathrm{~min}$, $56^{\circ} \mathrm{C}$ for $1 \mathrm{~min}$, and $72^{\circ} \mathrm{C}$ for 1 min (Guillemaut et al. 2003).

Each PCR product was digested using the endonucleases Mse I, Ava II, Mun I and Hinc II, separately; and after this, sample was incubated at $37^{\circ} \mathrm{C}$ for 3 hours. These enzymes are specific to differentiate among $R$. solani anastomosis groups. Ten $\mu \mathrm{L}$ of the PCR product was electrophoresed on $1.5 \%$ agarose gel, stained with ethidium bromide, illuminated and documented using Biorad UV Transilluminator. Each digestion enzyme generated a pattern from fungal DNA, which was encoded and compared with the specific code obtained for each reference strain (Guillemaut et al. 2003).

\section{Genetic Variability of Rhizoctonia solani}

Amplification of fungal DNA by repetitive extragenic palindromic elements (REP) from each $R$. solani strain was performing by PCR using ERIC1 primer (Godoy et al. 2004). The reaction was composed as follows: $2 \mu \mathrm{L}$ of $100 \mathrm{ng}$ DNA, $2.5 \mu \mathrm{L}$ of 10x buffer, $1 \mu \mathrm{L}$ of $50 \mathrm{mM} \mathrm{MgCl} 2,2 \mu \mathrm{l}$ of DNTP's at $2 \mathrm{mM}, 1.5 \mu \mathrm{L}$ of $10 \mathrm{pM}$ primer, and $0.25 \mu \mathrm{L}$ of $5 \mathrm{U} / \mu \mathrm{L}$ Taq DNA polymerase. PCR program was as follow: an initial denaturation for $7 \mathrm{~min}$ at $95^{\circ} \mathrm{C}, 30$ cycles of $1 \mathrm{~min}$ at $94^{\circ} \mathrm{C}, 1 \mathrm{~min}$ at $53^{\circ} \mathrm{C}$ and $8 \mathrm{~min}$ at $72^{\circ} \mathrm{C}$ and a final extension of $10 \mathrm{~min}$ at $72^{\circ} \mathrm{C}$.Ten $\mu \mathrm{L}$ of the PCR product were electrophoresed on $1 \%$ agarose gel, stained with ethidium bromide, illuminated and documented using Biorad UV Transilluminator. The polymorphism pattern was coded using a binary system (1 = presence, $0=$ absence); this data matrix was analyzed employing the info- Gen software (Balzarini \& Di-Rienzo 2003) to determine genetic diversity and analysis of molecular variance.

\section{Resistance of Rhizoctonia solani anastomosis groups to fungicides}

Each $R$. solani strain was grown on culture medium containing pencycuron $(0,0.025,0.05$, $0.1,0.25,0.5,0.75$ and $1.0 \mathrm{ppm})$ and thiabendazole $(0,0.5,1.0,1.5,2.0,3.0$ and $5.00 \mathrm{ppm})$. On this medium, a mycelia disc $(0.5 \mathrm{~cm})$ with active growth of each $R$. solani strain was placed, then the Petri Dish was sealed and incubated at $25 \pm 1{ }^{\circ} \mathrm{C}$. The radial growth was measured until the fungal strain growth in culture media without fungicide, completely covered the Petri dish. Each value was converted to inhibition percent of radial growth and this mycelial inhibition percent was employed to perform Probit analysis by maximum likelihood method using the SAS software (V.8.0) (http://support.sas.com/documentation/onlinedoc/v8/whatsnew/). The estimate doses on mycelial inhibition (\%) were obtained at a probability of 95\%. Later, the 50\% (IC50) and 90\% (IC90) inhibitory concentrations of each strain were obtained. The resistance factor (RF) was estimated by dividing the $\mathrm{IC}_{50}$ value of each strain by the $\mathrm{IC}_{50}$ value of the most susceptible reported strain. The $\mathrm{RF}$ indicates the number of times that an individual is more tolerant to an active substance than a susceptible individual (Leroux 1987).

\section{Results}

\section{Morphological characteristics}

A total of 57 Rhizoctonia spp. isolates were obtained from samples from potato plant roots, and tall with typical symptoms of Rhizoctonia root rot was isolated, as well as tuber sclerotic tissue.

\section{Anastomosis group characterization}

Restriction analysis of PCR products with enzymes, revealed different patterns. When these 
were compared to the patterns of the reference strains reported, it was possible to identify each strain at the level of anastomosis group (Fig. 1).

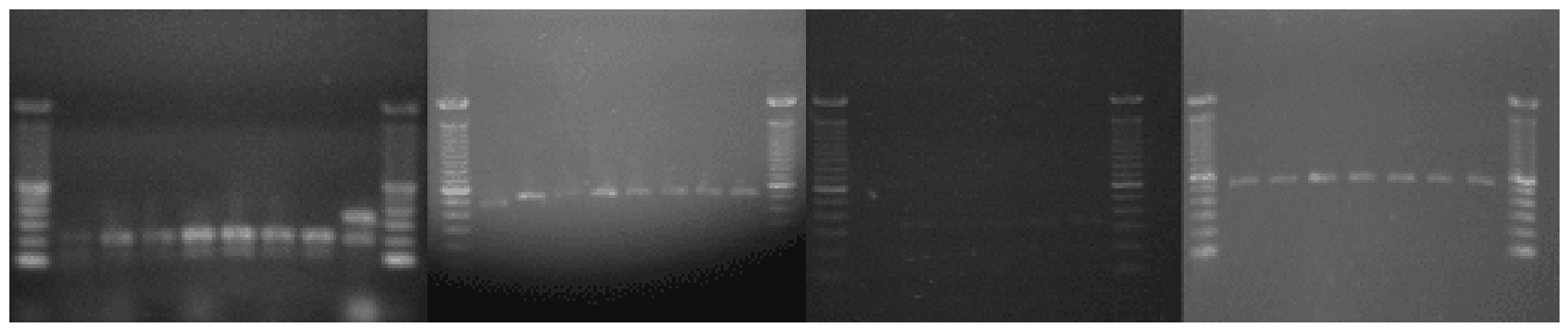

Fig. 1 - Restriction analysis generated by Mse I, Ava II, Hinc II and Mun I, enzymes (Sonora strains).

In Table 1, it can be observed that the AG-3 anastomosis group was found at the highest frequency and represented $81 \%$ of all fungal isolates, followed by AG1-1B with 14\%, and finally the AG-11 with 5\%.

Table 1 Rhizoctonia solani anastomosis group obtained by restriction profile comparative.

\begin{tabular}{|c|c|c|c|c|c|}
\hline Strain & Origen & $\begin{array}{l}\text { Anastomosis } \\
\text { group }\end{array}$ & Strain & Origen & $\begin{array}{l}\text { Anastomosis } \\
\text { group }\end{array}$ \\
\hline SO1 & Sonora & AG11 & A72 & Collection & AG3-PT \\
\hline SO2 & Sonora & AG3-PT & H33 & Collection & AG3-PT \\
\hline SO3 & Sonora & AG3-PT & IS & Collection & AG3-PT \\
\hline SO4 & Sonora & AG3-PT & A26 & Collection & AG11 \\
\hline SO5 & Sonora & AG3-PT & A77 & Collection & AG3-PT \\
\hline SO6 & Sonora & AG3-PT & A31 & Collection & AG3-PT \\
\hline SO8 & Sonora & AG3-PT & A79 & Collection & AG3-PT \\
\hline SO9 & Sonora & AG3-PT & JCH51 & Chihuahua & AG3-PT \\
\hline PC4 & Coahuila & AG3-PT & NCCH1 & Chihuahua & AG3-PT \\
\hline SJVC1 & Coahuila & AG3-PT & NCCH2 & Chihuahua & AG3-PT \\
\hline SJVC2 & Coahuila & AG3-PT & NCCH3 & Chihuahua & AG3-PT \\
\hline SJVC3 & Coahuila & AG3-PT & $\mathrm{NCCH} 4$ & Chihuahua & AG3-PT \\
\hline HC1 & Coahuila & AG1-1B & NCCH5 & Chihuahua & AG3-PT \\
\hline PC2 & Coahuila & AG3-PT & NCCH6 & Chihuahua & AG3-PT \\
\hline HC2 & Coahuila & AG3-PT & CA1 & Canada & AG3-PT \\
\hline PC3 & Coahuila & AG3-PT & CA2 & Canada & AG11 \\
\hline SJVC4 & Coahuila & AG1-1B & CA4 & Canada & AG3-PT \\
\hline SRNL1 & Nuevo Leon & AG1-1B & CA7 & Canada & AG1-1B \\
\hline SRNL2 & Nuevo Leon & AG3-PT & CA8 & Canada & AG3-PT \\
\hline SJNL1 & Nuevo Leon & AG3-PT & CA9 & Canada & AG3-PT \\
\hline SJNL2 & Nuevo Leon & AG3-PT & 76106 & Reference & AG8 \\
\hline SJNL4 & Nuevo Leon & AG3-PT & 76129 & Reference & AG6 \\
\hline SJNL5 & Nuevo Leon & AG3-PT & & & \\
\hline PNL1 & Nuevo Leon & AG3-PT & & & \\
\hline PNL2 & Nuevo Leon & AG1-1B & & & \\
\hline TJ1.1 & Jalisco & AG3-PT & & & \\
\hline TJ1.2 & Jalisco & AG3-PT & & & \\
\hline TJ1.3 & Jalisco & AG3-PT & & & \\
\hline TJ2.1 & Jalisco & AG3-PT & & & \\
\hline TJ2.2 & Jalisco & AG3-PT & & & \\
\hline TJ3.1 & Jalisco & AG3-PT & & & \\
\hline TJ3.3 & Jalisco & AG3-PT & & & \\
\hline TJ4.1 & Jalisco & AG3-PT & & & \\
\hline TJ4.3 & Jalisco & AG3-PT & & & \\
\hline TJ5.1 & Jalisco & AG1-1B & & & \\
\hline
\end{tabular}




\section{Anastomosis groups of Rhizoctonia solani and its resistance to fungicides}

The Probit analysis showed $\mathrm{IC}_{50}$ values indicating that resistance of pencycuron fungicide ranges from 0.014 to 0.039 (Table 2). There are reports that $\mathrm{IC}_{50}$ for a $R$. solani strain is $0.01 \mathrm{mg}$ a.i. $/ \mathrm{L}$ (Kataria et al. 1989). With these data, it was determined that the resistance factor (RF) of the studied strains ranged from 1.4 to 3.945 .

Table 2 Inhibitory concentration at 50 and $90 \%$ ( $\mathrm{IC}_{50}$ and $\mathrm{IC}_{90}$ ), and resistance factors to pencycuron fungicide in Rhizoctonia solani strains from different Mexican potato regions.

\begin{tabular}{|c|c|c|c|c|c|c|}
\hline Strains & $\mathrm{IC}_{50}(\mathrm{mg} / \mathrm{L})$ & LFL & UFL & $\mathrm{IC}_{90}(\mathrm{mg} / \mathrm{L})$ & RF & AG \\
\hline CA1 & 0.014 & 0.011 & 0.018 & 0.66 & 1.436 & AG3-PT \\
\hline SJVC1 & 0.018 & 0.002 & 0.042 & 0.294 & 1.436 & AG3-PT \\
\hline NCCH3 & 0.019 & 0.012 & 0.025 & 0.079 & 1.868 & AG3-PT \\
\hline SRNL2 & 0.020 & 0.017 & 0.023 & 0.072 & 2.001 & AG3-PT \\
\hline TJ4.3 & 0.021 & 0.013 & 0.027 & 0.073 & 2.075 & AG3-PT \\
\hline SJVC2 & 0.021 & 0.009 & 0.033 & 0.14 & 2.096 & AG3-PT \\
\hline TJ2.1 & 0.021 & 0.010 & 0.032 & 0.112 & 2.138 & AG3-PT \\
\hline SO3 & 0.021 & 0.019 & 0.024 & 0.06 & 2.145 & AG3-PT \\
\hline CA8 & 0.022 & 0.015 & 0.028 & 0.052 & 2.176 & AG3-PT \\
\hline SO4 & 0.022 & 0.019 & 0.024 & 0.052 & 2.184 & AG3-PT \\
\hline $\mathrm{NCCH} 4$ & 0.022 & 0.013 & 0.03 & 0.088 & 2.193 & AG3-PT \\
\hline TJ3.1 & 0.022 & 0.019 & 0.025 & 0.075 & 2.248 & AG3-PT \\
\hline PC4 & 0.023 & 0.011 & 0.03 & 0.063 & 2.255 & AG3-PT \\
\hline A79 & 0.023 & 0.020 & 0.026 & 0.076 & 2.296 & AG3-PT \\
\hline SO9 & 0.024 & 0.020 & 0.027 & 0.088 & 2.350 & AG3-PT \\
\hline NCCH6 & 0.024 & 0.017 & 0.03 & 0.078 & 2.370 & AG3-PT \\
\hline TJ1.1 & 0.024 & 0.021 & 0.026 & 0.063 & 2.385 & AG3-PT \\
\hline TJ4.2 & 0.024 & 0.021 & 0.027 & 0.073 & 2.410 & AG3-PT \\
\hline SO8 & 0.025 & 0.015 & 0.034 & 0.122 & 2.451 & AG3-PT \\
\hline NCCH5 & 0.026 & 0.023 & 0.028 & 0.067 & 2.552 & AG3-PT \\
\hline TJ1.3 & 0.026 & 0.020 & 0.031 & 0.066 & 2.570 & AG3-PT \\
\hline SO2 & 0.026 & 0.023 & 0.029 & 0.086 & 2.605 & AG3-PT \\
\hline PC3 & 0.027 & 0.013 & 0.039 & 0.118 & 2.656 & AG3-PT \\
\hline TJ4.1 & 0.027 & 0.018 & 0.036 & 0.106 & 2.740 & AG3-PT \\
\hline PNL1 & 0.028 & 0.020 & 0.036 & 0.135 & 2.766 & AG3-PT \\
\hline $1 \mathrm{~S}$ & 0.029 & 0.025 & 0.032 & 0.123 & 2.850 & AG3-PT \\
\hline NCCH1 & 0.029 & 0.013 & 0.045 & 0.180 & 2.857 & AG3-PT \\
\hline A77 & 0.029 & 0.025 & 0.033 & 0.132 & 2.915 & AG3-PT \\
\hline TJ2.2 & 0.032 & 0.026 & 0.038 & 0.105 & 3.222 & AG3-PT \\
\hline SJVC3 & 0.033 & 0.026 & 0.041 & 0.075 & 3.345 & AG3-PT \\
\hline TJ3.3 & 0.038 & 0.025 & 0.052 & 0.235 & 3.784 & AG3-PT \\
\hline SO6 & 0.027 & 0.019 & 0.035 & 0.103 & 2.724 & AG3-PT \\
\hline CA7 & 0.017 & 0.010 & 0.024 & 0.095 & 1.739 & AG1-1B \\
\hline STNL1 & 0.027 & 0.023 & 0.031 & 0.163 & 2.691 & AG1-1B \\
\hline SRNL4 & 0.030 & 0.016 & 0.045 & 0.187 & 3.9047 & AG1-1B \\
\hline PNL2 & 0.039 & 0.031 & 0.048 & 0.126 & 3.945 & AG1-1B \\
\hline A26 & 0.020 & 0.010 & 0.028 & 0.107 & 1.955 & AG11 \\
\hline
\end{tabular}

IC $=$ Inhibition concentration, LFL $=$ Lower Fiducial Limits, UFL $=$ Upper Fiducial Limits, RF $=$ Resistance Factor, AG = Anastomosis Group

With the thiabendazole fungicide, $R$. solani strains showed $\mathrm{IC}_{50}$ values lesser than $2.91 \mathrm{mg}$ a.i./L, this suggests that all tested strains are susceptible. According to Leach \& Murdoch (1985), a 
strain is susceptible to thiabendazole if the $\mathrm{IC}_{50}$ value is less than $3 \mathrm{mg} / \mathrm{L}$, as in this study (Table 3). Results of this study coincide with those reported by Holguin (1999), who did not find any $R$. Solani strains that were resistant to this fungicide.

Table 3 Inhibitory Concentrations at 50 and $90 \%$ ( $\mathrm{IC}_{50}$ and $\mathrm{IC}_{90}$ ) and resistance factors to thiabendazol fungicide in Rhizoctonia solani strains from different Mexican potato regions.

\begin{tabular}{|c|c|c|c|c|c|c|}
\hline Strains & $\mathrm{IC}_{50}(\mathrm{mg} / \mathrm{L})$ & LFL & UFL & $\mathrm{IC}_{90}(\mathrm{mg} / \mathrm{L})$ & RF & AG \\
\hline PC4 & 0.82 & 0.62 & 1 & 2.54 & 0.27 & AG3-PT \\
\hline TJ2.1 & 0.88 & 0.72 & 1.03 & 1.81 & 0.29 & AG3-PT \\
\hline TJ3.1 & 0.91 & 0.72 & 1.09 & 1.96 & 0.30 & AG3-PT \\
\hline SJVC2 & 0.93 & 0.69 & 1.15 & 2.5 & 0.31 & AG3-PT \\
\hline A31 & 0.93 & 0.77 & 1.08 & 1.86 & 0.31 & AG3-PT \\
\hline SO9 & 0.92 & 0.79 & 1.04 & 1.98 & 0.31 & AG3-PT \\
\hline SO3 & 0.94 & 0.68 & 1.18 & 1.83 & 0.31 & AG3-PT \\
\hline A77 & 0.96 & 0.77 & 1.15 & 2.41 & 0.32 & AG3-PT \\
\hline SO4 & 0.96 & 0.90 & 1.01 & 2.35 & 0.32 & AG3-PT \\
\hline CA8 & 0.99 & 0.79 & 1.18 & 1.84 & 0.33 & AG3-PT \\
\hline NCCH5 & 0.98 & 0.67 & 1.26 & 2.01 & 0.33 & AG3-PT \\
\hline NCCH6 & 0.99 & 0.87 & 1.10 & 2.35 & 0.33 & AG3-PT \\
\hline TJ4.3 & 0.99 & 0.84 & 1.13 & 2.41 & 0.33 & AG3-PT \\
\hline SO8 & 0.99 & 0.82 & 1.16 & 2.36 & 0.33 & AG3-PT \\
\hline SO2 & 1 & 0.82 & 1.17 & 2.22 & 0.33 & AG3-PT \\
\hline CA1 & 1.01 & 0.82 & 1.18 & 2.5 & 0.34 & AG3-PT \\
\hline NCCH4 & 1.06 & 1.01 & 1.12 & 2.43 & 0.35 & AG3-PT \\
\hline SJVC1 & 1.05 & 1 & 1.10 & 2.29 & 0.35 & AG3-PT \\
\hline $1 \mathrm{~S}$ & 1.06 & 1.01 & 1.12 & 2.62 & 0.35 & AG3-PT \\
\hline TJ4.1 & 1.06 & 0.87 & 1.24 & 1.93 & 0.35 & AG3-PT \\
\hline PNL1 & 1.06 & 0.73 & 1.38 & 2.39 & 0.35 & AG3-PT \\
\hline TJ1.1 & 1.04 & 0.77 & 1.29 & 2.4 & 0.35 & AG3-PT \\
\hline TJ1.3 & 1.11 & 0.9 & 1.32 & 2.63 & 0.37 & AG3-PT \\
\hline SRNL2 & 1.12 & 0.91 & 1.33 & 2.91 & 0.37 & AG3-PT \\
\hline NCCH1 & 1.14 & 0.95 & 1.33 & 2.87 & 0.38 & AG3-PT \\
\hline NCCH3 & 1.15 & 1.04 & 1.27 & 2.61 & 0.38 & AG3-PT \\
\hline TJ3.3 & 1.14 & 0.85 & 1.42 & 2.43 & 0.38 & AG3-PT \\
\hline PC3 & 1.18 & 1.01 & 1.36 & 2.44 & 0.39 & AG3-PT \\
\hline SO6 & 1.16 & 1.05 & 1.27 & 2.44 & 0.39 & AG3-PT \\
\hline A79 & 1.19 & 1.14 & 1.24 & 2.45 & 0.40 & AG3-PT \\
\hline TJ2.2 & 1.19 & 0.99 & 1.38 & 3 & 0.40 & AG3-PT \\
\hline TJ4.2 & 1.19 & 0.9 & 1.5 & 2.54 & 0.40 & AG3-PT \\
\hline SJVC3 & 1.34 & 1.03 & 1.65 & 2.8 & 0.45 & AG1-1B \\
\hline CA7 & 0.87 & 0.71 & 1.01 & 1.9 & 0.29 & AG1-1B \\
\hline SRNL1 & 2.06 & 1.73 & 2.49 & 5.79 & 0.69 & AG1-1B \\
\hline PNL2 & 2.43 & 2.05 & 3.05 & 31.5 & 0.81 & AG1-1B \\
\hline SJVC4 & 2.91 & 2.4 & 3.73 & 6.07 & 0.97 & AG1-1B \\
\hline A26 & 0.98 & 0.92 & 1.03 & 2.28 & 0.33 & AG11 \\
\hline
\end{tabular}

IC $=$ Inhibition concentration, LFL $=$ Lower Fiducial Limits, UFL $=$ Upper Fiducial Limits, RF $=$ Resistance Factor, AG= Anastomosis Group

\section{Genetic Variability of Rhizoctonia solani}

The analysis of molecular variance (AMOVA) detected significant differences among origin groups (localities and/or States) (P-value 0.03) and within these (isolates) (P-value 0.025). 
Polymorphism analysis included 28 bands obtained by REP-PCR of 48 isolates from $R$. Solani from five potato producing Mexican States, including two reference groups (one from own collection, and ATTC $^{\circledR}$ strains) a variation range between 0.43 (Chihuahua) to 0.86 polymorphic loci from reference strains was observed $\left(\right.$ ATCC $^{\circledR} 76106^{\mathrm{TM}}$ and ATCC $^{\circledR} 76129^{\mathrm{TM}}$ ), with a total value of 0.89 (Table 4).

Table 4 Genetic variability descriptors of Rhizoctonia solani isolates.

\begin{tabular}{lllllllll}
\hline \multirow{2}{*}{ Statistic } & \multicolumn{9}{c}{ Isolates } & \multirow{2}{*}{ Total } \\
\cline { 2 - 8 } & $\mathbf{1}$ & $\mathbf{2}$ & $\mathbf{3}$ & $\mathbf{4}$ & $\mathbf{5}$ & $\mathbf{6}$ & $\mathbf{7}$ & \\
\hline Polymorphic loci & 0.68 & 0.79 & 0.43 & 0.71 & 0.86 & 0.75 & 0.75 & 0.89 \\
Genetic Diversity & 0.23 & 0.28 & 0.17 & 0.23 & 0.34 & 0.29 & 0.25 & 0.29 \\
Unbiased Heterozygosis & 0.25 & 0.31 & 0.19 & 0.24 & 0.37 & 0.31 & 0.26 & 0.30 \\
(Nei) & & & & & & & & \\
Allele average & 1.68 & 1.79 & 1.43 & 1.71 & 1.86 & 1.75 & 1.75 & 2.00 \\
Effective allele & 1.39 & 1.47 & 1.30 & 1.38 & 1.59 & 1.50 & 1.40 & 1.47 \\
\hline
\end{tabular}

1 = Coahuila, 2 = Canada, 3 = Chihuahua, 4 = Jalisco, 5 = Reference, 6 = Nuevo León, 7 = Sonora

\section{Discussion}

\section{Morphological characteristics}

All isolates showed typical features of $R$. solani complex (Fig. 2) including brown pigmentation of hyphae, branching near distal septum, constriction of hyphae and formation of a septum at a short distance from the place of branching, and the presence of dolipore septa, and multinuclear cells in young vegetative hyphae (Parmeter \& Whitney 1970).

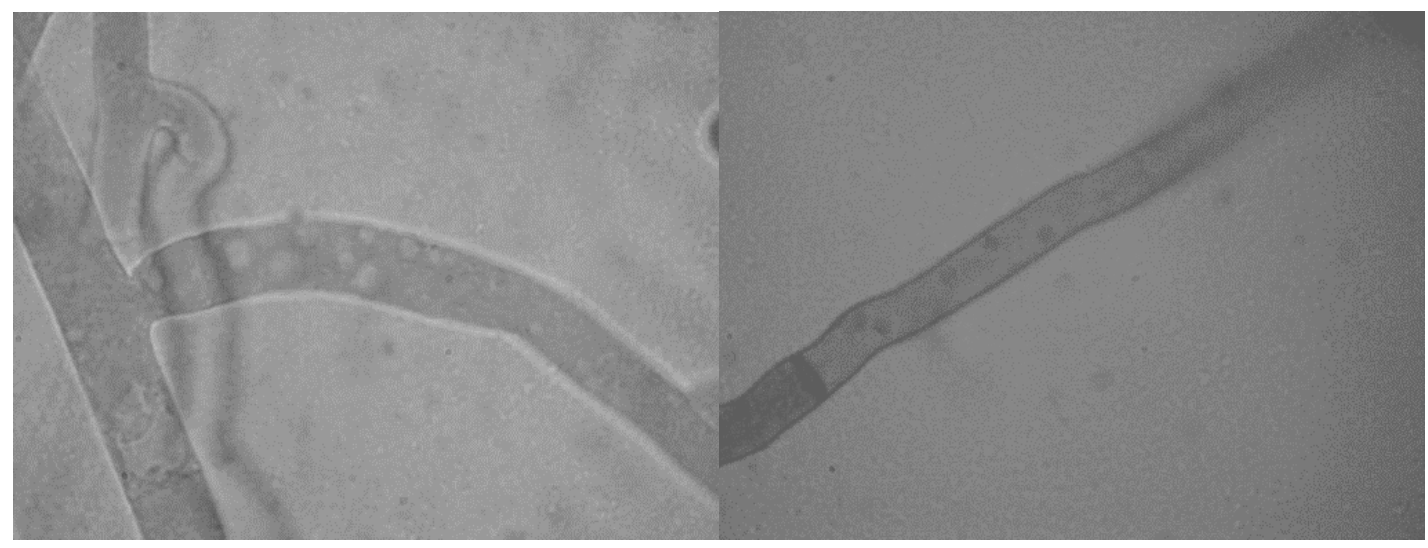

Fig. 2 - Morphological typical characteristic and multinuclear cells of Rhizoctonia solani.

\section{Anastomosis group characterization}

These results are consistent with most reports, indicating that GA-3 is the group most commonly associated with potato crop (Bandy et al. 1988, Carling \& Leiner 1990). However, there are reports on other anastomosis groups such as AG-1, AG-2-1, AG-2-2, AG-4, AG-5 and AG-9 that are attacking potato crop (Carling \& Leiner 1990). Other authors have reported for Mexico, that AG-3, AG-2, AG-4, AG-5 and AG-7 groups attacked potato crop; and these groups were identified by the confrontation technique (Holguin 1999, Virgen et al. 2000, Hernández et al. 2001, 2005). This is the first report about AG11 and AG1-1B anastomosis groups associated with potato in Mexico. The highest incidence of AG-3 in potato can be related to its origin associated with sclerotic tissue on the tuber, where $R$. solani isolates were obtained for this study, these results seem to agree with those mentioned by Platt et al. (1993), who reported AG-3 isolates from tubers and other anastomosis groups different to AG-3 when isolates are obtained from soil or infected stems. Similar results are reported by Montero et al. (2013). These authors isolated different AG 
groups from pepper where stem and roots were used. They mainly isolated fungal strains belonging to AG-4, AG-7, and AG-13 and in minor proportion isolates belonging to AG-12, AG-11, AG22IV, AG-2-2IIIB and AG-2-1 groups.

\section{Anastomosis groups of Rhizoctonia solani and their resistance to fungicides}

The RF values were higher than the unit, so it is considered that the $R$. solani isolates were resistant to pencycuron (Koller \& Scheinpflug 1987, Leroux 1987). Resistance to pencycuron has been reported by other authors. $R$. solani strains belonging to AG-3 group and isolated from potatoes from Chihuahua showed IC $_{50}$ from 0.002 to 1.04 (Hernández et al. 2005) and $R$. solani strains isolated from different regions of Mexico, also showed resistance to pencycuron (Holguin 1999, Chávez et al. 2011).

Several reports indicated that there are differences among anastomosis groups on tolerance to both fungicides evaluated in this study. It is observed that the anastomosis group more tolerant to both fungicides is AG-11; this behavior has been previously reported by several authors, indicating that each anastomosis group tolerates different concentrations of fungicides (Lehtonen et al. 2008a). For the pencycuron fungicide, Hernández et al. (2005) and Chávez et al. (2011) reported a RF for the AG-4 group of 225.9 and 104.4 for AG-3. These values are higher than those observed in this study, but the tendency is the same.

\section{Genetic Variability of Rhizoctonia solani}

The population used as a reference, showed the highest genetic diversity value (0.34) (Table 4); this is because its individuals are genetically distinct (AG-6, AG-8, AG-3, and AG-11), while the Chihuahua population showed the lowest genetic variability (0.17), which may be due to Chihuahuan regions remained isolated from introduction of potato seed tuber from Canada in the early 90's, so there are fewer genotypes of Rhizoctonia. Moreover, Chihuahua is the oldest region where potato is planted in Mexico, so individuals that are less fit may disappear, thus reducing genetic variability. Also, the lowest values of unbiased heterozygotes were showed by the Chihuahuan population with 0.19 , and the highest values by the reference (GA-6 and GA-8) population with 0.37 . The average number of alleles ranged from 1.43 to 1.86 among populations. The highest genetic variability was observed in the control group (0.34), which is given because in this group have different anastomosis groups, in contrast, the population from Chihuahua had the lowest (0.17) variability, where all $R$. solani isolates were identified as belonging to the same anastomosis group. Genetic diversity was very low in most populations; this is attributed to that this fungus spreads asexually (mycelium and sclerotic tissue which spreads through seed tuber). There are few reports of parasexual cycle in $R$. solani, which has not been completely deciphered for this species, even though, it is a phenomenon with some occurrence (Parameter, 1970). According to the results generated in this study, genetic variability of $R$. solani in the studied populations could be generated only by mutation and gene flow.

The average genetic diversity observed in this study (0.29) is similar to that of 0.2945 reported by Ceresini et al. (2002), also a low value of this measure, reflects low recombination, so that, the greatest effects of asexual reproduction is production of few recombinant genotypes, and low genetic diversity. Although, the occurrence of duplicate genotypes was not observed, the low genetic diversity may indicate a clonal reproduction of the analyzed isolations, and low parasexual cycle. In the analysis of molecular variance (Table 5), significant differences between (p-value 0.03 ) and within populations ( $p$-value 0.02 ) were found, where genetic variability among populations was two-fold higher than variability within populations. We consider a population as derived from locality, where each population is adapted to climatic conditions of the zone and each zone has specific characteristics, so this genetic variability is due in response to adaptive evolution. In contrast, the high similarity observed within populations can be due that were isolating few anastomosis groups among the population, and they express heightener similarity of allele. In addition; therefore, it is likely that less diversity exists among the strains analyzed in the same population (Saavedra \& Spoor 2002). 
Table 5 Analysis of molecular variance (AMOVA) among anastomosis groups.

\begin{tabular}{llllll}
\hline Variation & SS & FD & MS & P-VALUE & Number of interactions \\
\hline Population & 13.43 & 1 & 13.43 & $<0.03$ & 400 \\
Within & 316.15 & 41 & 7.71 & $<0.0225$ & 400 \\
Total & 329.58 & 42 & 7.85 & & \\
\hline
\end{tabular}

\section{References}

Anderson NA. 1982 - The genetics and pathology of Rhizoctonia solani. Annual Review of Phytopathology 20, 329-347.

Balzarini M, Di-Rienzo J. 2003 - InfoGen. Software para análisis estadísticos de marcadores genéticos. Facultad de Ciencias Agropecuarias. Universidad Nacional de Córdoba. Argentina.

Bandy BP, Leach SS, Tavantzis SM. 1988 - Anastomosis group 3 is the major Cause of Rhizoctonia disease of potato in Maine. Plant Disease 72, 596-598.

Banville GJ. 1989 - Yield losses and damage to potato plants caused by Rhizoctonia solani Kühn. American Potato Journal 66, 821-34.

Bolton MD, Panella L, Campbell L, Khan MFR. 2010 - Temperature, moisture, and fungicide effects in managing Rhizoctonia root and crown rot of sugar beet. Phytopathology 100, 689697.

Carling DE, Kuninaga S, Brainard KA. 2002 - Hyphal anastomosis reactions, rDNA-internal transcribed spacer sequences, and virulence levels among subsets of Rhizoctonia solani anastomosis group-2 (AG-2) and AG-BI. Phytopathology 92, 43-50.

Carling DE, Leiner RH. 1990 - Effect of temperature on virulence of Rhizoctonia solani and other Rhizoctonia on potato. Phytopathology 80, 930-934.

Ceresini PC, Shew HD, Vilgalys RJ, Cubeta MA. 2002 - Genetic diversity of Rhizoctonia solani AG-3 from potato and tobacco in North Carolina. Mycologia 94(3), 437-449.

Doi: 10.1080/15572536.2003.11833209

Chávez BJR, Hernández CFD, Gallegos MG, Rodríguez HR. 2011 - Susceptibilidad al Pencycuron, de grupos de asnastomosis de Rhizoctonia solani Kühn en ocho regiones paperas de México. Revista Agraria -Nueva Epoca- Año VIII 8(3), 18-24.

Chen Y, Zhang AF, Wang WX, Zhang Y, Gao TC. 2012 - Baseline sensitivity and efficacy of thifluzamide in Rhizoctonia solani. Annals of Applied Biology 161, 247-254.

Doi:10.1111/j.1744-7348.2012.00569.x

Cubeta MA, Vilgalys R. 1997 - Population biology of the Rhizoctonia solani complex. Phytopathology 87, 480-484.

Dellaporta SL, Wood J, Hicks JB. 1983 - A plant DNA minipreparation. Version ll. Plant Molecular Biology Reporter 1, 19-21

Godoy P, Cano J, Gené J, Guarro J et al. 2004 - Genotyping of 44 isolates of Fusarium solani, the main agent of fungal keratitis in Brazil. Journal of Clinical Microbiology 42(10), 4494-4497. Doi: 10.1128/JCM.42.10.4494-4497.2004

González HD. 2002 - Estado actual de la taxonomía de Rhizoctonia solani Kühn. Revista Mexicana de Fitopatología 20(2), 200-2005.

Goswami BK, Rahaman MM, Hoque AKMA, Bhuyan K, Mian IH. 2011 - Variations in different isolates of Rhizoctonia solani based on temperature and $\mathrm{pH}$. Journal of Agricultural Research 36(3), 389-396.

Guillemaut C, Edel-Hermann V, Camporota P, Alabouvette C, Steinberg C. 2003 - Typing of anastomosis groups of Rhizoctonia solani by restriction analysis of ribosomal DNA. Canadian Journal of Microbiology 49, 556-568.

Hane JK, Anderson JP, Williams AH, Sperschneider J, Singh KB. 2014 - Genome sequencing and comparative genomics of the broad host-range pathogen Rhizoctonia solani AG8. PLoS Genet 10(5), e1004281. Doi: 10.1371/journal.pgen.1004281 
Hannukkala AO, Rastas M, Laitinen P, Latvala S. 2016 - Rhizoctonia solani injuries in oilseed crops in Finland and impacts of different crop management practices on disease incidence and severity. Annals of Applied Biology 169, 257-273. Doi: 10.1111/aab.12293

Hernández CFD, Cepeda SM, García CJ, Pérez ChA. 2001 - Grupos de anastomosis de Rhizoctonia solani de la región papera de Toluca estado de México y susceptibilidad in vitro a fungicidas de diferente grupo toxicológico. Agraria 17(2), 59-64.

Hernández FD, Carvajal CR, Guerrero E, Sánchez A et al. 2005 - Susceptibilidad a fungicidas de grupos de anastomosis del hongo Rhizoctonia solani Kühn colectado en zonas paperas de Chihuahua, Mexico. Phyton, International Journal of Experimental Botany 74, 259-269.

Holguin PRJ. 1999 - Niveles de tolerancia a fungicidas de diferente grupo toxicológico y pruebas de adaptabilidad de Rhizoctoniasolani y $R$. cereales de las regiones paperas de Coahuila, Nuevo León, Chihuahua, Guanajuato y Toluca. Tesis de Maestría. Universidad Autónoma Agraria Antonio Narro, México.

Huynh VK, Akihiro N. 2016 - Effects of temperature on growth and photosynthesis in the seedling stage of the sheath blight-resistant rice genotype 32R. Plant Production Science 19(2), 246256.

Kataria HR, Singh H, Gisi U. 1989 - Interactions of fungicide-insecticide combinations against Rhizoctonia solani in vitro and in soil. Crop protection 8, 399-404.

Kataria HR, Verma PR, Gisi U. 1991 - Variability in the selectivity of Rhizoctonia solani anastomosis groups to fungicides. Phytopathology 133(2), 121-133.

Koller W, Scheinpflug H. 1987 - Fungal resistance to sterol biosynthesis inhibitors: a new challenge. Plant Disease 71, 1066-1074.

LaMondia JA. 2012 - Efficacy of azoxystrobin fungicide against sore shin of shade tobacco caused by Rhizoctonia solani, Tobacco Science 49, 1-3. Doi: 10.3381/11-014.1

Leach SS, Murdoch CW. 1985 - Evaluation of thiabendazol and pentachloronitrobenzene for control of the Rhizoctonia disease complex on white potato (Solanum tuberosum L.). American Journal of Potato Research 62(9), 459-469.

Lehtonen MJ, Ahvenniemi P, Wilson PS, German-Kinnari M, Valkonen JPT. 2008a - Biological diversity of Rhizoctonia solani (AG-3) in a northern potato-cultivation environment in Finland. Plant Pathology 57, 141-151.

Lehtonen MJ, Somervuo P, Valkonen JPT. 2008b - Infection with Rhizoctonia solani induces defense genes and systemic resistance in potato sprouts grown without light. Phytopathology 98, 1190-1198.

Leroux P. 1987 - La resistence des champignons aux fongicides I. Phytoma 385, 6-15.

Montero TV, Guerrero ABZ, Anaya LJL, Martínez MTO et al. 2013-Genetic diversity of Rhizoctonia solani isolates (Kuhn) from pepper in Mexico. Revista Mexicana de Ciencias Agricolas 4(7), 1043-1054.

Mu W, Wang Z, Bi Y, Ni X et al. 2017 - Sensitivity determination and resistance risk assessment of Rhizoctonia solani to SDHI fungicide thifluzamide. Annals of Applied Biology 170, 240250.

Ogoshi A. 1996 - Introduction the genus Rhizoctonia. In. Rhizoctonia species: taxonomy, molecular biology, ecology, pathology and disease control. Eds. Sneh B, Jabaji-Hare S, Neate Sand Dijst G. Kluwer Academic Publishers, The Netherlands. pp. 1-9.

Pannecoucque J, Van Beneden S, Höfte M. 2008 - Characterization and pathogenicity of Rhizoctonia isolates associated with cauliflower in Belgium. Plant Pathology 57, 737-746. Doi: 10.1111/j.1365-3059.2007.01823.x

Parmeter JR Jr, Whitney HS. 1970 - Taxonomy and nomenclature of the imperfect state. Pages 719 in: J. R. Parmeter Jr., (ed.) Biology and Pathology of Rhizoctonia solani. University of California Press, Berkeley. 255 pp.

Platt HW, Canale E, Gimenez G. 1993 - Effect of tuber-borne inoculum of Rhizoctonia solani and fungicidal seed potato treatment on plant growth and Rhizoctonia disease in Canada and Uruguay. American Journal of Potato Research 70, 553-559. 
Saavedra G, Spoor W. 2002 - Genetic base broadening in autogamous crops: Lycopersicon esculentum Mill. as a model. In: Engels JMM, Rao VR, Brown AHD, Jackson MT (Eds) Managing Plant Genetic Diversity, CABI Pub-lishing, Wallingford, UK, pp 291-299.

Stacy RB, Kenneth EC. 2004 - Characterization of Rhizoctonia solani Isolates Associated with Patch Diseases on Turfgrass. Proc. Okla. Acad. Sci. 84, 41-51.

Sturrock CJ, Woodhall J, Brown M, Walker C et al. 2015 - Effects of damping-off caused by Rhizoctonia solani anastomosis group 2-1 on roots of wheat and oil seed rape quantified using X-ray Computed Tomography and real-time PCR. Frontiers in Plant Science 6, 461. Doi: $10.3389 /$ fpls.2015.00461

Virgen CG, Olalde PV, Carling DE. 2000 - Anastomosis groups of Rhizoctonia solani on potato in central Mexico and potential for biological and chemical control. American Journal of Potato Research 77, 219-224.

Wibberg D, Jelonek L, Rupp O, Hennig M et al. 2013 - Establishment and interpretation of the genome sequence of the phytopathogenic fungus Rhizoctonia solani AG1-IB isolate 7/3/14. Journal of Biotechnology 167, 142-155. Doi: 10.1016/j.jbiotec.2012.12.010

Woodhall BJW, Lees AK, Edwards SG, Jenkinson P. 2007 - Characterization of Rhizoctonia solani from potato in Great Britain. Plant Pathology 56,286-295.

Doi: 10.1111/j.1365-3059.2006.01545.x 